\title{
ANALISIS EFISIENSI BANK PEMBIAYAAN RAKYAT SYARIAH (BPRS) WILAYAH JAWA TENGAH \& DIY DENGAN METODE DATA ENVELOPMENT ANALYSIS (DEA) PERIODE 2016 - 2018
}

\author{
Ulfi Hidayah $^{1}$, Atieq Amjadallah Alfie ${ }^{2}$, Rosida Dwi Ayuningtyas ${ }^{3}$
}

\begin{abstract}
This study aims to analyze the efficiency level of BPRS in the Central Java and DIY regions during the 2016-2018 period using the Data Envelopment Analysis (DEA) method. This study uses input variables consisting of third party funds, operating expenses and fixed assets, and uses output variables consisting of financing and operating income. This research uses quantitative methods and the data used is secondary data obtained from the financial reports of BPRS for the Central Java and DIY regions.. Based on calculations using the Banxia Frontier Analysis software, of the 33 BPRS that were sampled there were only 6 BPRS which always achieved $100 \%$ efficiency levels during 2016-2018, consisting of 2 BPRS in the Central Java region and 4 BPRS in the DIY area, namely PT. BPRS Sukowati Sragen and PT. BPRS Harta Insan Karimah Bahari for the Central Java region, PT. BPRS Madina Mandiri Sejahtera, PT. BPRS Mitra Amal Mulia, PT. BPRS Danagung Syariah and PT. BPRS Mitra Harmoni Yogyakarta for the DIY area. The rest has not yet reached efficiency. This inefficient is caused by a lack of productive financing distribution.
\end{abstract}

Keywords: Efficiency, Data Envelopment Analysis (DEA), Islamic People's Financing Bank

\section{PENDAHULUAN}

Bank merupakan lembaga yang melakukan penghimpunan dana dari masyarakat dan menyalurkan kepada masyarakat dalam bentuk pembiayaan atau disebut dengan fungsi intermediasi keuangan. Terdapat dua jenis perbankan di Indonesia, yaitu perbankan konvensional dan perbankan syariah. Perbankan syariah di Indonesia terdiri dari Bank Umum Syariah (BUS) dan Bank Pembiayaan Rakyat Syariah (BPRS), serta ada Unit Usaha Syariah (UUS) sebagai unit dari bank konvensional yang menjalankan usaha sesuai dengan prinsip syariah, sesuai dengan Undang-Undang Nomor 21 tahun 2008.

\footnotetext{
${ }^{1}$ Mahasiswa Program Studi Ekonomi Islam, Fakultas Ekonomi, Universitas Wahid Hasyim

${ }^{2}$ Dosen Program Studi Akuntansi, Fakultas Ekonomi, Universitas Wahid Hasyim

3 Dosen Program Studi Ekonomi Islam, Fakultas Ekonomi, Universitas Wahid Hasyim/ rosida@unwahas.ac.id
} 
Bank Pembiayaan Rakyat Syariah (BPRS) mempunyai peran yang cukup berpengaruh terhadap perkembangan Usaha Mikro dan Kecil (UMK) baik dipedesaan maupun perkotaan. Munculnya Bank Pembiayaan Rakyat Syariah (BPRS) semakin menambah daftar nama perbankan syariah, karena Bank Pembiayaan rakyat Syariah (BPRS) merupakan sebuah lembaga keuangan yang memenuhi kebutuhan masyarakat atas transaksi pembiayaan yang tanpa riba. Jika melihat data di Otoritas Jasa Keuangan (OJK), perkembangan Bank Pembiayaan Rakyat Syariah (BPRS) saat ini ada 164 Bank Pembiayaan Rakyat Syariah (BPRS), yang terdistribusi jaringan kantor terbesar di 18 provinsi di Indonesia. Berikut ini tabel perkembangan BPRS di Indonesia :

Tabel 1.1

\section{Jumlah BPRS di Indonesia}

\begin{tabular}{|c|c|}
\hline Tahun & Jumlah \\
\hline 2011 & 155 \\
\hline 2012 & 158 \\
\hline 2013 & 163 \\
\hline 2014 & 163 \\
\hline 2015 & 163 \\
\hline 2016 & 166 \\
\hline 2017 & 167 \\
\hline 2018 & 168 \\
\hline 2019 & 164 \\
\hline
\end{tabular}

Sumber : Otoritas Jasa Keuangan (2019)

BPRS hanya terfokus melayani Usaha Mikro dan Kecil yang memiliki proses mudah, pelayanan cepat, dan persyaratan mudah (Bank Indonesia, 2008). Bank Pembiayaan Rakyat Syariah (BPRS) memiliki prosedur pelayanan yang sederhana, proses yang cepat, dan skema kredit yang mudah disesuaikan, serta lokasi yang tersebar diperkotaan maupun dipedesaan (Septianto dan Widiharih, 2010). Ketua Peneliti Stranas Hibah Kemenristek Dikti, Etty Susilowati (2018) mengatakan, persaingan di wilayah perbankan mikro sangat ketat dihadapi oleh BPRS. Para pelaku perkreditan yang berfokus pada wilayah Usaha Mikro Kecil dan Menengah (UMKM) cukup banyak. Bukan hanya BPRS yang memfasilitasi permodalan para pelaku UMKM. Oleh karena itu diperlukan pengukuran efisiensi untuk menunjang kinerja BPRS.

Efisiensi pada perbankan digunakan sebagai alat ukur kinerja bank apakah bank tersebut mengalami kinerja yang baik atau tidak. Jika sebuah bank mempunyai efisiensi yang maksimal, maka bank tersebut mengalami kinerja yang baik dan bank mengalami kemajuan, tetapi sebaliknya jika efisiensi tidak maksimal maka bank mengalami kinerja kurang baik yang memicu terjadinya kemunduran pada bank. Menurut Huri dan Susilowati (2004) dan Hartono et al (2008) mengungkapkan bahwa efisiensi didefinisikan sebagai perbandingan antara keluaran (output) dengan masukan (input), atau jumlah keluaran yang dihasilkan dari satu input yang dipergunakan. Pengukuran efisiensi merupakan salah satu aspek untuk memeriksa kinerja suatu perusahaan. 
Efisiensi tersebut dapat diukur dalam tiga cara, memaksimalkan output, meminimalisasi biaya, dan memaksimalisasi keuntungan (Mokhtar, 2008). Ketika pengukuran efisiensi dilakukan, bank dihadapkan pada kondisi bagaimana mendapatkan tingkat output yang optimal dengan tingkat input yang ada, atau mendapatkan tingkat input yang minimum dengan tingkat output tertentu. Dengan begitu dapat dianalisa lebih jauh untuk melihat penyebab ketidakefisienan (Hadad ed al., 2003).

Sebagai objek penelitian, provinsi Jawa Tengah memiliki beberapa keunggulan, seperti tempat wisata, banyaknya industri, perdagangan, ataupun Usaha Mikro Kecil Menengah (UMKM). Namun jika dilihat dari perkembangan BPRS di Provinsi Jawa Tengah, tampak bahwa di Provinsi Jawa Tengah mempunyai asset, pembiayaan, DPK, FDR, dan NPF yang cukup baik jika dibandingkan dengan daerah-daerah di pulau Jawa lainnya. Berdasarkan tautan semarangpos (2019), Otoritas Jasa Keuangan (OJK) Kantor Regional III Jawa Tengah dan DIY mencatat kinerja BPRS di Jateng hingga Maret 2019 tumbuh positif.

Kemudian Perbankan Syariah di Daerah Istimewa Yogyakarta (DIY) menaruh optimisme yang tinggi pada prospek 2019. Pencapaian positif selama 2018 baik nasional maupun DIY serta perkembangan keuangan syariah DIY yang menggembirakan menjadi landasan optimisme tersebut. Ketua Dewan Pimpinan Wilayah (DPW) Asosiasi Bank Syariah Indonesia (Asbisindo) Daerah Istimewa Yogyakarta (DIY) Sukma Dwie Priardi menyebutkan secara keseluruhan industri perbankan syariah DIY mengalami tren positif dan berhasil memiliki pertumbuhan yang lebih tinggi dibanding dengan rata-rata pertumbuhan industri perbankan syariah secara nasional (www.harianjogja.com, 2019).

Berdasarkan tautan ekbis.sindonews (2019), kinerja Bank Perkreditan Rakyat (BPR) di Daerah Istimewa Yogyakarta masih positif meski saat ini kondisi perekonomian masih mengalami perlambatan. Hal ini menurut Otoritas Jasa Keuangan (OJK) karena nasabah kini memilih produk dari Bank Pembiayaan Rakyat Syariah (BPRS). OJK Yogyakarta melihat, pertumbuhan kredit atau pembiayaan dari BPR Konvensional terhadap BPRS justru lebih kecil. Belakangan masyarakat lebih memilih kredit BPRS ketimbang melalui BPR Konvensional. Hal tersebut dapat dilihat dari data perumbuhan kredit BPR Konvensional tahun 2016 lalu, yang hanya tumbuh 8,81\% dibanding tahun 2015. Sementara pembiayaan yang dikucurkan BPRS selama periode Januari-Desember 2016 meningkat 14,3\% dibanding periode yang sama tahun sebelumnya, (Linangkung, 2017). Berdasarkan latar belakang diatas, peneliti tertarik untuk meniliti efisiensi BPRS wilayah Jateng dan Daerah Istimewa Yogyakarta. Penelitian ini memfokuskan pada pengukuran efisiensi BPRS wilayah Jawa Tengah dan Daerah Istimewa Yogyakarta (DIY) periode 2016 - 2018 dengan metode Data Envelpoment Analysis (DEA) menggunakan pendekatan intermediasi dan pendekatan produksi dilihat dari variabel input dan outputnya. 


\section{Bank Pembiayaan Rakyat Syariah (BPRS)}

Bank Perkreditan Rakyat Syariah (BPRS) adalah bank yang melaksanakan kegiatan usaha berdasarkan prisnsip Syari'ah yang dalam kegiatannya tidak memberikan jasa dalam lalu lintas pembayaran. Bentuk hukumnya dapat berupa: Perseroan Terbatas/PT, Koperasi atau Perusahaan Daerah (Pasal 2 PBI No. 6/17/PBI/2004). Undang-undang Nomor 21 Tahun 2008 menyebutkan Bank Pembiayaan Rakyat Syariah (BPRS) yaitu Bank Syariah yang dalam kegiatannya tidak memberikan jasa dalam lalu lintas pembayaran. Yang perlu diperhatikan dari ketentuan diatas adalah kepanjangan dari BPR Syariah yang berupa Bank Perkreditan Syariah. Ini berarti semua peraturan perundangan-undangan yang menyebut BPR Syariah dengan Bank Perkreditan Rakyat Syariah harus dibaca dengan Bank Pembiayaan Rakyat Syariah (BPRS).

Pasal 1 UU No. 21 Tahun 2008 tentang Ketentuan Umum disebutkan pengertian dari Bank Pembiayaan Rakyat Syariah (BPRS) adalah Bank Syariah yang dalam kegiatanya tidak memberikan jasa dalam lalu lintas pembayaran. BPRS merupakan badan usaha yang setara dengan bank perkreditan rakyat konvensional dengan bentuk hokum perseroan terbatas, perusahaan daerah, atau koperasi.

\section{Teori Efisiensi}

Efisiensi merupakan perbandingan output dan input yang berhubungan dengan tercapainya output maksimum dengan sejumlah input tertentu (Coelli et al., 2005). Jika ratio output input besar maka efisiensi dikatakan semakin tinggi. Dengan demikian, efisiensi adalah penggunaan input yang terbaik dalam memproduksi output. Menurut Abidin \& Endri (2009) menyatakan bahwa efisiensi sebuah perusahaan terdiri dari dua komponen, yaitu efisiensi teknis (technical efficiency) dan efisiensi alokatif (allocative efficiency). Efisiensi teknis menunjukan kemampuan perusahaan untuk mencapai output semaksimal mungkin dari jumlah input. Sedangkan efisiensi alokatif menunjukan kemampuan perusahaan untuk menggunakan input dengan proporsi seoptimal mungkin pada tingkat harta input tertentu. Kedua komponen ini kemudian dikombinasikan untuk menghasilkan ukuran efisiensi total atau efisiensi ekonomis (economic efficiency). Suatu perusahaan dikatakan efisien apabila (Muharam \& Pusvitasari, 2007):

a. Menggunakan jumlah unit input yang lebih sedikit bila dibandingkan dengan jumlah unit input yang digunakan oleh perusahaan lain dengan menghasilkan jumlah output yang sama.

b. Menggunakan jumlah unit input yang sama, dapat menghasilkan jumlah output yang lebih besar.

\section{Data Envelopment Analysis (DEA)}

Data Evelopment Analysis (DEA) pertama kali diperkenalkan oleh Charnes, Cooper dan Rhodes pada tahun 1978 dan 1979. Semenjak itu pendekatan dengan metode Data Envelopmen Analysis (DEA) banyak digunakan penelitian - penelitian 
operasional dan ilmu manajemen. Pendekatan DEA lebih menekankan pendekatan yang berorientasi kepada tugas dan lebih memfokuskan kepada tugas yang penting, yaitu mengevaluasi kinerja dari unit pembuat keputusan (DMU/Decision Making Units) (Machmud dan Rukmana, 2010: 123). DEA merupakan metode non parametrik yang digunakan dalam mengukur tingkat efisiensi suatu Unit Kegiatan Ekonomi (UKE). Selain itu, DEA merupakan metode untuk mengevaluasi efisiensi dari suatau unit pengambilan keputusan (unit kerja) yang bertanggung jawab menggunakan sejumlah input untuk memperoleh suatu output yang ditargetkan (Firdaus dan Hosen, 2013: 172). Pada awalnnya dikembangkan untuk pengukuran kinerja, dan sekarang aplikasi DEA telah dipakai sebagai pengukuran pada berbagai disiplin ilmu pengetahuan dan berbagai kegiatan operasional (Cooper, Seiford dan Tone, 2000).

Metodologi ini berhasil diterapkan untuk mengukur kinerja relatif dari sekumpulan perusahaan yang menggunakan beragam input identik untuk menghasilkan beragam output identik. Prinsip-prinsip DEA diperkenalkan oleh Farrel (1957) yang kemudian dikembangkan secara luas oleh Charnes, Cooper dan Rhodes (1978) (Ventelou dan Bry dalam Heny, 2012: 120). Pada metode ini efisiensi dinyatakan dalam rasio antara total input dengan total output tertimbang. Dimana setiap unit kegiatan ekonomi diasumsikan bebas menentukan bobot untuk setiap variabel input maupun variable output yang ada, asalkan mampu memenuhi dua kondisi yang disyaratkan yaitu:

a. Bobot tidak boleh negatif.

b. Bobot harus bersifat universal atau tidak menghasilkan indikator efisiensi yang di atas normal atau lebih besar dari nilai 1, bilamana dipakai unit kegiatan ekonomi yang lainnya.

Angka efisiensi yang diperoleh dengan model DEA memungkinkan untuk mengidentifikasi unit kegiatan ekonomi yang penting diperhatikan dalam kebijakan pengembangan kegiatan ekonomi yang dijalankan secara kurang produktif (Silkman dalam Heny, 2012: 121). Data Envelopment Analysis menghitung nilai h, dimana h adalah nilai masing-masing periode BPRS. DEA memaksimalkan $h$, dimana $h$ adalah jumlah perkalian antara bobot output I dengan jumlah output I pada periode BPRS tersebut (Komaryatin, 2007).

Selanjutnya ditentukan kriteria penilaian UPK, dalam hal ini bank dikatakan efisien jika menunjukkan $\mathrm{h}=1$ atau $100 \%$ dan sebaliknya, dikatakan tidak efisien jika nilai $\mathrm{h}<0$ atau kurang dari 100\%. Dalam DEA setiap UPK menentukan pembobotnya masing-masing dan pembobot yang dipilih akan menghasilkan ukuran kinerja yang baik (Dwi Ariefand, 2014: 7).

Selain menentukan input dan output, pada pengukuran tingkat efisiensi terdapat 2 model yang digunakan dalam menganalisis efisiensi suatu Unit Kegiatan Ekonomi (UKE), yaitu: Model yang pertama kali dikembangkan adalah model dengan asusmsi Constant Return to Scale (CRS) atau biasa disebut model Charnes-Cooper-Rhode 
(CCR). Dalam model CRS ini mengasumsikan bahwa rasio antara penambahan input dan output adalah sama. Jika ada tambahan input sebesar $\mathrm{x}$ kali, maka output akan meningkat sebesar x kali juga. Menurut Charnes, Cooper, dan Rhodes model ini dapat menunjukkan technical afficiency secara keseluruhan atau nilai dari profit efficiency untuk setiap Unit Kegiatan Ekonomi.

Model kedua yang dikembangkan dalam pengukuran tingkat efisiensi adalah model dengan asumsi Variable Return to Scale (VRS) atau biasa disebut dengan model BCC (Bankers-Charnes-Cooper). Model ini berasumsi bahwa rasio antara penambahan input dan output tidak sama. Artinya, penambahan input sebesar x kali tidak akan menyebabkan output meningkat sebesar $\mathrm{x}$ kali, bisa lebih kecil atau lebih besar dari $\mathrm{x}$ kali. Persaingan tidak sempurna, kendala keuangan dan sebagainya mungkin menyebabkan sebuah perusahaan tidak beroperasi pada skala yang optimal.

Penelitian ini menggunakan metode Data Envelopment Analysis (DEA), karena menurut Purwantoro (2004), DEA mempunyai beberapa keunggulan diantaranya:

a. Dapat menangani banyak input dan output.

b. Tidak membutuhkan asumsi hubungan antar variabel input dan output.

c. Input dan Output dapat memiliki satuan pengukuran yang berbeda tanpa perlu melakukan perubahan satuan dari kedua variabel tersebut.

Pengukuran efisiensi dengan menggunakan metode DEA membutuhkan adanya variabel input dan output. Menurut Purwantoro (2004) identifikasi pengukuran perbandingan efisiensi kinerja merupakan langkah pertama dan terpenting karena hasil evaluasi kinerja nantinya akan sangat bergantung pada pemilihan variabel input output yang dipakai. Dalam pendekatan intermediasi, variabel input ditransformasikan menjadi berbagai bentuk output yang dihasilkan dari input-input yang ada sebelumnya.

\section{METODE PENELITIAN}

\section{Jenis Penelitian}

Penelitian ini menggunakan metode kuantitatif berlandaskan pada suatu peristiwa yang benar-benar terjadi. Metode ini digunakan untuk meneliti pada populasi atau sampel tertentu. Dalam penelitian ini, metode kuantitatif digunakan untuk menghitung besarnya tingkat efisiensi BPRS Wilayah Jawa Tengah dan DIY.

\section{Jenis dan Sumber Data}

Penelitian ini menggunakan data sekunder Laporan Keuangan masing-masing BPRS wilayah Jawa Tengah dan DIY tahun 2016 - 2018 yang diperoleh dari data dan statistik perbankan syariah dari webesite Otoritas Jasa Keuangan (OJK).

\section{Populasi Penelitian}

Populasi dalam penelitian ini merupakan seluruh BPRS wilayah Jawa Tengah yang berjumlah 26 kantor BPRS dan DIY yang berjumlah 12 kantor BPRS. 


\section{Sampel dan Teknik Pengambilan Sampel}

Sampel yang digunakan diambil dari populasi BPRS yang beroperasi di Jawa Tengah dan DIY selama periode 2016-2018. Pengambilan sampel dalam penelitian ini dilakukan secara purposive sampling yaitu metode pemilihan sampel dipilih berdasarkan kriteria-kriteria tertentu.

\section{Teknik Pengumpulan Data}

Teknik pengumpulan data yang digunakan penulis adalah metode studi pustaka, yaitu pengumpulan data melalui pengkajian buku - buku literatur, jurnal - jurnal ilmiah dan website resmi lembaga pengkajian keuangan syariah untuk memperoleh landasan teori yang akurat dan memperoleh laporan keuangan yang dibuat oleh BPRS terkait.

\section{Definisi Operasional Variabel}

Pada penelitian ini, menggunakan metode Data Envelopment Analysis (DEA) untuk mengukur tingkat efisiensi dengan menggunakan pendekatan intermediasi yang terdiri dari variabel input dan output. Variabel pada penelitian ini sebagai berikut :

\begin{tabular}{|c|l|l|}
\hline Variabel Input & \multicolumn{1}{|c|}{ Definisi } & Sumber \\
\hline Dana Pihak Ketiga & $\begin{array}{l}\text { Dana pihak ketiga biasanya lebih dikenal } \\
\text { dengan dana masyarakat, merupakan dana yang } \\
\text { dihimpun oleh bank yang berasal dari } \\
\text { masyarakat dalam arti luas meliputi } \\
\text { masyarakat individu, maupun badan usaha. }\end{array}$ & Neraca \\
\hline Beban operasional & $\begin{array}{l}\text { Beban operasional adalah biaya yang } \\
\text { berhubungan atau mempengaruhi langsung } \\
\text { pada aktivitas perusahaan, dengan kata lain } \\
\text { beban operasional merupakan sumber ekonomi } \\
\text { dalam upaya mempertahankan dan } \\
\text { menghasilkan pendapatan operasional. }\end{array}$ & \\
\hline Aset tetap & $\begin{array}{l}\text { Aset bank dengan masa pakai diatas satu tahun, } \\
\text { tidak untuk dijual guna menunjang kegiatan } \\
\text { operasional bank, antara lain tanah, gedung dan } \\
\text { peralatan yang dimiliki atau disewa. }\end{array}$ & Neraca \\
\hline
\end{tabular}

\begin{tabular}{|l|l|l|}
\hline Variabel Output & \multicolumn{1}{|c|}{ Definisi } & Sumber \\
\hline Pembiayaan & $\begin{array}{l}\text { Fasilitas pendanaan atau penyediaan dana baik } \\
\text { berupa uang atau tagihan yang dapat }\end{array}$ & Neraca \\
& $\begin{array}{l}\text { dipersamakan dengan itu, oleh suatu pihak } \\
\text { (lembaga) kepada pihak lain dengan }\end{array}$ & \\
& $\begin{array}{l}\text { persyaratan atau mewajibkan pihak yang } \\
\text { dibiayai untuk mengembalikan uang atau }\end{array}$ & \\
\hline
\end{tabular}




\begin{tabular}{|l|l|l|}
\hline & $\begin{array}{l}\text { tagihan tersebut setelah jangka waktu yang } \\
\text { sudah disepakati bersama dengan imblan } \\
\text { maupun tanpa imblan dan bagi hasil. }\end{array}$ & \\
\hline $\begin{array}{l}\text { Pendapatan } \\
\text { operasional }\end{array}$ & $\begin{array}{l}\text { Pendapatan yang diperoleh perusahaan sabagai } \\
\text { hasil dari usaha pokok perusahaan. }\end{array}$ & Laba rugi \\
\hline
\end{tabular}

\section{Teknik Analisi Data}

Alat analisis dalam penelitian ini menggunakan metode Data Envelopment Analysis (DEA). Dalam proses pengolahan Data Envelopment Analysis menggunakan software Banxia Frontier Analysis dengan menggunakan pendekatan output oriented. Menurut Firdaus dan Hosen (2013: 172) DEA merupakan metode non parametrik yang digunakan dalam mengukur tingkat efisiensi suatu Unit Kegiatan Ekonomi (UKE). Selain itu DEA merupakan metode yang digunakan untuk mengevaluasi efisiensi dari suatu unit pengambilan keputusan (unit kerja) yang bertanggung jawab menggunakan sejumlah input untuk memperoleh suatu output yang ditargetkan.

Ada dua model yang sering digunakan dalam pendekatan ini, yaitu Constant Return to Scale (CRS) dan Variable Return to Scale (VRS). Model CRS mengasumsikan bahwa rasio antara penambahan input dan output adalah sama. Artinya, jika ada tambahan input sebesar " $x$ " kali, output akan meningkat sebesar " $x$ " kali juga. Asumsi yang lain yang digunakan dalam model ini adalah bahwa setiap perusahaan atau UPK beroperasi pada skala yang optimal (Machmud dan Rukmana, 2010: 124).

Sedangkan model VRS atau disebut dengan model BCC (Bankers CharnesCooper) beranggapan bahwa perusahaan tidak atau belum beroperasi pada skala yang optimal. Asumsi model ini adalah bahwa rasio antara penambahan input dan output tidak sama. Artinya, penambahan input sebesar " $x$ " kali tidak akan menyebabkan output meningkat sebesar "x" kali, bisa lebih kecil atau lebih besar. (Machmud dan Rukmana, 2010: 125).

Metode DEA mengukur efisiensi secara relatif dari Decision Making Unit (DMU) yang dianalisis. Tidak ada batasan minimal jumlah DMU yang harus dianalisis. Akan tetapi, biasanya lebih dari lima unit supaya terhindar dari self indertifer. Data Envelopment Analysis menghitung nilai h, dimana h adalah nilai masing-masing periode BPRS. DEA memaksimalkan $\mathrm{h}$, dimana $\mathrm{h}$ adalah jumlah perkalian antara bobot output I dengan jumlah output I pada periode BPRS tersebut (Komaryatin, 2007: 107).

Berdasarkan hasil analisis data-data tersebut, selanjutnya ditentukan kriteria penilaian UPK, dalam hal ini bank dikatakan efisien jika menunjukkan $\mathrm{h}=1$ atau $100 \%$ dan sebaliknya, dikatakan tidak efisien jika nilai $\mathrm{h}<0$ atau kurang dari $100 \%$. Setiap UPK menentukan pembobotnya masing-masing dan pembobot yang dipilih akan menghasilkan ukuran kinerja yang baik (Ismail, dkk dalam Ariefand, 2014:7).

Angka efisiensi yang diperoleh dari hasil olah data DEA memungkinkan untuk mengidentifikasi unit kegiatan ekonomi yang penting diperhatikan dalam menentukan 
kebijakan pengembangan kegiatan ekonomi yang dijalankan secara kurang produktif. Suatu perusahaan yang rasional selalu berupaya untuk memaksimalkan keuntungan yang diperolehnya. Sehingga perusahaan harus bersifat sensitif terhadap isu yang berhubungan dengan skala hasil (return to scale). Perusahaan akan memiliki salah satu dari kondisi Return to Scale, yaitu Increasing Return to Scale (IRS), Constant Return to Scale (CRS) dan Decreasing Return to Scale (DRS) (Erwinta S. dan Arafat, 2004). Kondisi tersebut dapat diperoleh dengan cara sebagai berikut :

a. Kondisi IRS bilamana nilai $\Sigma \lambda<1$ dari model CCR dan $\lambda$ tersebut adalah nilai hasil penghitungan dari DEA.

b. Kondisi CRS bilamana nilai efisiensi CCR $=1$ atau $\Sigma \lambda=1$ untuk model CCR.

c. Kondisi DRS bilamana nilai $\Sigma \lambda>1$ dari model CCR.

Jika suatu perusahaan dalam kondisi IRS berarti penambahan $1 \%$ input akan menambahkan lebih dari $1 \%$ output dan oleh karenanya perusahaan tersebut pasti akan terus menambah kapasitas produksinya. Hal yang sama juga akan dilakukan untuk perusahaan untuk menjaga hasil produksinya pada kondisi CRS, yang berarti bahwa penambahan $1 \%$ input akan menghasilkan penambahan $1 \%$ output. Akhirnya, perusahaan akan menurunkan inputnya apabila dari hasil perhitungan berada pada kondisi DRS, yang berarti jika input ditambah 1\% maka output akan kurang dari $1 \%$.

Data Envelopment Analysis (DEA) memiliki beberapa nilai manajerial. Pertama, DEA menghasilkan efisiensi untuk setiap Unit Kegiatan Ekonomi (UKE) di dalam sampel. Angka efisiensi ini dapat dijadikan dasar oleh manajemen untuk mengenali UKE yang paling membutuhkan perhatian dan merencanakan tindakan perbaikan bagi Unit Kegiatan Ekonomi (UKE) yang tidak/kurang efisien. Kedua, jika suatu Unit Kegiatan Ekonomi (UKE) kurang efisien (efisiensi<100\%), maka DEA dapat menunjukkan sebuah Unit Kegiatan Ekonomi (UKE) yang memiliki efisiensi sempurna (efficient reference set, efisien $=100 \%$ ) dan seperangkat angka pengganda (multiplers) yang dapat digunakan oleh manajemen untuk menyusun strategi perbaikan.

\section{HASIL DAN PEMBAHASAN}

Penelitian ini menggunakan data sekunder berupa laporan keuangan Bank Pembiayaan Rakyat Syariah di Jawa tengah dan Daerah Istimewa Yogyakarta dengan jumlah 33 BPRS. Data penelitian ini diperoleh dari website Otoritas Jasa Keuangan (OJK). Populasi yang digunakan adalah seluruh BPRS wilayah Jawa Tengah yang berjumlah 26 kantor BPRS dan DIY yang berjumlah 12 kantor BPRS, dengan total keseluruhan adalah 38 BPRS.

Teknik yang digunakan untuk pengambilan sampel dalam penelitian ini menggunakan teknik purposive sampling, yaitu teknik pengambilan sampel dengan kriteria tertentu yang sudah ditentukan sebelumnya. Berdasarkan kriteria diatas, diperoleh sampel sebanyak 33 BPRS yang sesuai dengan teknik purposive sampling, 
yang terdiri dari 21 kantor BPRS wilayah Jawa Tengah dan 12 kantor BPRS wilayah Daerah Istimewa Yogyakarta.

Nilai efisiensi pada penelitian ini diperoleh dari hasil proses perhitungan menggunakan software Banxia Frontier Analysis. Software ini akan memberikan skor 0-1 kemudian diubah dalam bentuk presentase $0-100 \%$ pada tiap-tiap DMU dalam objek penelitian. DMU dikatakan efisien apabila memiliki skor efisiensi 1 atau 100\%, sedangkan DMU yang memiliki skor efisiensi kurang dari 1 atau 100\% dinyatakan tidak efisien. Skor efisiensi tersebut merupakan perbandingan antara input dan output pada masing-masing DMU.

Selain menunjukkan skor efisiensi, software Banxia Frontier Analysis juga akan menunjukkan nilai terget. Nilai target yaitu nilai yang disarankan oleh perhitungan DEA agar bank menjadi lebih efisien. Berdasarkan hasil perhitungan metode DEA, dapat dilihat tingkat efisiensi BUS

berikut ini:

Tabel Nilai Efisiensi Bank Pembiayaan Rakyat Syariah (BPRS)

Wilayah Jawa Tengah Tahun 2016-2018

\begin{tabular}{|l|c|c|c|}
\hline \multirow{2}{*}{ NAMA BANK } & \multicolumn{3}{|c|}{ TAHUN } \\
\cline { 2 - 4 } & $\begin{array}{c}\mathbf{2 0 1 6} \\
\text { (persen) }\end{array}$ & $\begin{array}{c}\mathbf{2 0 1 7} \\
\text { (persen) }\end{array}$ & $\begin{array}{c}\mathbf{2 0 1 8} \\
\text { (persen) }\end{array}$ \\
\hline BPRS Artha Amanah Ummat & $92,89 \%$ & $100 \%$ & $70,85 \%$ \\
\hline BPRS Asad Alif & $100 \%$ & $68,37 \%$ & $55,13 \%$ \\
\hline BPRS Gala Mitra Abadi & $50,65 \%$ & $62,61 \%$ & $54,22 \%$ \\
\hline BPRS Artha Mas Abadi & $76,42 \%$ & $76,69 \%$ & $51,29 \%$ \\
\hline BPRS Saka Dana Mulia & $78,41 \%$ & $100 \%$ & $49,45 \%$ \\
\hline BPRS Bina Amanah Satria & $59,58 \%$ & $92,93 \%$ & $57,37 \%$ \\
\hline BPRS Khasanah Ummat & $48,86 \%$ & $96,49 \%$ & $45,77 \%$ \\
\hline BPRS Arta Leksana & $78,57 \%$ & $89,57 \%$ & $57,95 \%$ \\
\hline BPRS Suriyah & $100 \%$ & $100 \%$ & $72,03 \%$ \\
\hline BPRS Bumi Artha Sampang & $69,00 \%$ & $74,23 \%$ & $100 \%$ \\
\hline BPRS Buana Mitra Perwira & $100 \%$ & $100 \%$ & $82,22 \%$ \\
\hline BPRS Ikhsanul Amal & $55,26 \%$ & $59,83 \%$ & $48,76 \%$ \\
\hline BPRS AL Mabrur Klaten & - & - & $100 \%$ \\
\hline BPRS Dharma Kuwera & $59,67 \%$ & $47,54 \%$ & $59,36 \%$ \\
\hline BPRS Sukowati Sragen & $100 \%$ & $100 \%$ & $100 \%$ \\
\hline BPRS Insan Madani & $100 \%$ & $100 \%$ & $97,86 \%$ \\
\hline BPRS Artha Surya Barokah & $77,96 \%$ & $80,35 \%$ & $63,71 \%$ \\
\hline BPRS Bina Finansia & - & - & $100 \%$ \\
\hline $\begin{array}{l}\text { BPRS Mitra Harmoni Kota } \\
\text { Semarang }\end{array}$ & $100 \%$ & $85,11 \%$ & $73,45 \%$ \\
\hline $\begin{array}{l}\text { BPRS Harta Insan Karimah } \\
\text { Bahari }\end{array}$ & $100 \%$ & $100 \%$ & $100 \%$ \\
\hline BPRS Dana Mulia & $81,89 \%$ & $60,64 \%$ & $86,30 \%$ \\
\hline
\end{tabular}




\section{Nilai Efisiensi Bank Pembiayaan Rakyat Syariah (BPRS)}

Wilayah DIY Tahun 2016-2018

\begin{tabular}{|l|c|c|c|}
\hline \multirow{2}{*}{\multicolumn{1}{|c|}{ NAMA BANK }} & \multicolumn{3}{|c|}{ TAHUN } \\
\cline { 2 - 4 } & $\begin{array}{c}\mathbf{2 0 1 6} \\
\text { (persen) }\end{array}$ & $\begin{array}{c}\mathbf{2 0 1 7} \\
\text { (persen) }\end{array}$ & $\begin{array}{c}\mathbf{2 0 1 8} \\
\text { (persen) }\end{array}$ \\
\hline BPRS Margirizki Bahagia & $96,16 \%$ & $100 \%$ & $86,10 \%$ \\
\hline BPRS Bangun Drajat Warga & $64,03 \%$ & $97,39 \%$ & $83,83 \%$ \\
\hline BPRS Madina Mandiri Sejahtera & $100 \%$ & $100 \%$ & $100 \%$ \\
\hline BPRS Cahaya Hidup & $91,32 \%$ & $90,78 \%$ & $88,43 \%$ \\
\hline BPRS Mitra Amal Mulia & $100 \%$ & $100 \%$ & $100 \%$ \\
\hline BPRS Danagung Syariah & $100 \%$ & $100 \%$ & $100 \%$ \\
\hline BPRS Mitra Cahaya Indonesia & $88,17 \%$ & $100 \%$ & $100 \%$ \\
\hline BPRS FORMES & $77,18 \%$ & $76,39 \%$ & $69,74 \%$ \\
\hline BPRS Dana Hidayatullah & $85,37 \%$ & $95,40 \%$ & $88,61 \%$ \\
\hline BPRS Barokah Dana Sejahtera & $85,50 \%$ & $76,31 \%$ & $90,37 \%$ \\
\hline BPRS Mitra Harmoni Yogyakarta & $100 \%$ & $100 \%$ & $100 \%$ \\
\hline BPRS Unisia Insan Indonesia & $45,83 \%$ & $91,08 \%$ & $92,84 \%$ \\
\hline
\end{tabular}

Hasil penelitian ini menjelaskan bahwa jumlah input dan output Bank Pembiayaan Rakyat Syariah mengalami peningkatan dan penurunan dari tahun ke tahun, sedangkan rata-rata efisiensi BPRS mengalami fluktuasi selama periode pengamatan. Selain bankbank yang sudah mengalami efisiensi, ada pula bank-bank yang mengalami inefisiensi. Inefisiensi itu sendiri yaitu kondisi dimana bank tersebut tidak beroperasi secara maksimal dalam hal penggunaan dana.

Dari 33 BPRS yang digunakan, yang terdiri dari 2 wilayah yaitu 21 BPRS wilayah Jawa Tengah dan 12 BPRS wilayah Daerah Istimewa Yogyakarta (DIY), untuk wilayah Jawa Tengah hanya ada 2 BPRS yang mengalami efisiensi, sedangkan 19 BPRS mengalami inefisiensi, yang meliputi: PT. BPRS Artha Amanah Ummat, PT. BPRS Asad Alif, PT. BPRS Gala Mitra Abadi, PT. BPRS Artha Mas Abadi, PT. BPRS Saka Dana Mulia, PT. BPRS Bina Amanah Satria, PT. BPRS Khasanah Ummat, PT. BPRS Artha Leksana, PT. BPRS Suriyah, PT. BPRS Bumi Artha Sampang, PT. BPRS Buana Mitra Perwira, PT. BPRS Ikhsanul Amal, PT. BPRS Al Mabrur Klaten, PT. BPRS Dharma Kuwera, PT. BPRS Insan Madani, PT.BPRS Artha Surya Barokah, PT. BPRS Bina Finansia, PT. BPRS Mitra Harmoni Kota Semarang dan PT. BPRS Dana Mulia.

Kemudian dari 12 BPRS di wilayah Daerah Istimewa Yogyakarta (DIY) ada 4 BPRS yang mengalami efisiensi, sedangkan 8 BPRS lainnya mengalami inefisiensi, yaitu meliputi: PT. BPRS Margirizki Bahagia, PT. BPRS Bangun Drajat Warga, PT. BPRS Cahaya Hidup, PT. BPRS Mitra Cahaya Indonesia, PT. BPRS FORMES, PT. BPRS Dana Hidayatullah, PT. BPRS Barokah Dana Sejahtera dan PT. BPRS Unisia 
Insan Indonesia. Dan presentase terkecil dialami oleh BPRS Khasanah Ummat pada tahun 2018 yaitu mencapai angka 45,77\%.

Dalam pengukuran DEA, bank dikatakan efisien apabila menunjukkan skor 1, sedangkan untuk bank yang inefisien, skor tidak mencapai angka 1. Ketidakefisienan tersebut disebabkan kurang maksimalnya target input dan outputnya. Inefisiensi terjadi pada variabel input (dana pihak ketiga, beban operasional dan aset tetap) dan variabel output (pembiayaan dan pendapatan operasional). Dilihat dari hasil penelitian diatas menunjukkan bahwa BPRS wilayah Daerah Istimewa Yogyakarta (DIY) memiliki tingkat efisiensi yang lebih baik dibandingkan dengan BPRS di wilayah Jawa Tengah.

\section{KESIMPULAN}

Berdasarkan analisi yang telah dilakukan pada bab sebelumnya, maka kesimpulan yang dapat diambil adalah:

a. BPRS di wilayah Daerah Istimewa Yogyakarta memiliki tingkat efisiensi yang lebih baik dibandingkan dengan BPRS di wilayah Jawa Tengah.

b. Dari 33 BPRS yang menjadi sampel penelitian, hanya terdapat 6 BPRS yang selalu mencapai tingkat efisiensi 100\% selama tahun 2016-2018, tediri dari 2 BPRS di wilayah Jawa Tengah dan 4 BPRS di wilayah DIY, yaitu PT. BPRS Sukowati Sragen dan PT. BPRS Harta Insan Karimah Bahari untuk wilayah Jawa Tengah, PT. BPRS Madina Mandiri Sejahtera, PT. BPRS Mitra Amal Mulia, PT. BPRS Danagung Syariah dan PT. BPRS Mitra Harmoni Yogyakarta untuk wilayah DIY.

c. Ketidakefisienan 27 BPRS tersebut terjadi pada semua variabel input (dana pihak ketiga, beban operasional dan aset tetap), dan variabel outputnya (total pembiayaan). Ketidakefisienan input hampir dialami oleh setiap BPRS. Hal ini menandakan penggunaan input yang berlebihan dan tidak sesuai target. Pada sisi output total pembiayaan hanya dialami oleh beberapa BPRS. Hal tersebut menandakan bahwa output yang dihasilkan masih belum maksimal dan mencapai target yang ditentukan. BPRS yang inefisien diharapkan mengacu kepada BPRS yang lebih efisien dengan menggunakan bobot input-output sesuai dengan hasil pengukuran metode DEA. Artinya bahwa BPRS yang inefisien mencontoh tingkat penggunaan input dan output dari BPRS yang efisien agar dapat meningkat efisiensi teknik $100 \%$.

\section{DAFTAR PUSTAKA}

Chuzaimah, et al. (2017). "Mengukur Tingkat Efisiensi Bank Pembiayaan Rakyat Syari'ah Dengan Menggunakan Data Envelopment Analysis (DEA)". Jurnal Studi Islam, Vol. XII, No. 2.

Deby Oktavia, M. (2018). "Analisis Efisiensi Bank Umum Konvensional Di Indonesia Dengan Pendekatan Data Envelopment Analysis (DEA)". Yogyakarta: UNY. 
Early Ridho, K. (2018). "Evaluasi Ingkat Efisiensi Bank Pembiayaan Rakyat Syariah Di Provinsi Aceh Dengan Metode Data Envelopment Analysis". j-EBIS, Vol. 3 No. 1.

Eva Permata, M. (2017). "Analisis Efisiensi Bank Pembiayaan Rakyat Syari'ah Dengan Metode Data Envelopment Analysis Pada PT. BPRS Lantabur Tebuireng Periode 2011-2016". Surakarta: FEBI IAIN Surakarta.

Fadhil, M. N. dan Achmad Firdaus. (2017). “Analisis Efisiensi Bank Pembiayaan Rakyat Syariah (BPRS) Wilayah Jabodetabek Dengan Pendekatan Two Stage Data Envelopment Analysis (DEA)". Jurnal Ekonomi Syariah, Volume 5, Nomor 2.

Fathony, Moch. (2013). “Analisis Efisiensi Perbankan Nasional Berdasarkan Ukuran Bank: Pendekatan Data Envelopment Analysis”. Finance and Banking Journal.

Hadad, Muliaman D., et al. (2003). Analisis Efisiensi Industri Perbankan Indonesia: Penggunaan Metode Non-parametrik Data Envelopment Analysis (DEA), Biro Stabilitas Sistem Keuangan Bank Indonesia, Research Paper.

Harjum Muharam, Rizki Pusvitasari. (2007). “Analisis Perbandingan Efisiensi Bank Syariah di Indonesia Dengan Metode Data Envelopment Analysis". Fakultas Ekonomi Universitas Diponegoro Semarang, Vol. 2 No.3.

https://m.harianjogja.com/ekbis/read/2019/01/21/502/966391/perbankan-syariah-diytunjukkan-tren-positif

https://www.gatra.com/detail/news/364833-Potensi-BPRS-di-Tengah-EkonomiMilenial

Mahmud Fauzi. (2018). "Efisiensi Bank Pembiayaan Rakyat Syariah (BPRS) Di Provinsi Jawa Tengah”. Jurnal Ekonomi dan Keuangan Islam, Vol. 4 No. 1.

Mei Lina, Q. (2017). “Analisis Efisiensi Bank Pembiayaan Rakyat (BPR) Syariah Dan Bank Pembiayaan Rakyat (BPR) Konvensional Di Sukoharjo Dengan Menggunakan Metode Data Envelopment Analysis (DEA) Periode 20132015”. Surakarta: FEBI UMS.

Muhammad. (2002). “Manajemen Bank Syari'ah,” Yogyakarta: UPP AMP, h. 56.

Nonie Afrianty dan Moh Bekti, H. A. (2017). "Tingkat Persaingan Dan Efisiensi Bank Pembiayaan Rakyat Syariah Di Indonesia". Jurnal Baabu Al-Ilmi Ekonomi dan Perbankan Syariah, Vol. 2 No. 1.

Syafa'at Muhari dan Muhammad, N. H. (2014). "Tingkat Efisiensi Bprs Di Indonesia: Perbandingan Metode SFA Dengan DEA Dan Hubungannya Dengan CAMEL”. Jurnal Keuangan dan Perbankan, Vol. 18, No. 2.

www.bps.go.id

www.ojk.go.id

Zakiatun Nisak. (2017). “Analisis Pelaksanaan Kerjasama Penjaminan Pembiayaan Bank Syariah Di Pt. Jaminan Pembiayaan Askrindo Syariah KPS Surabaya Dengan Metode Data Envelopment Analysis (DEA)". Surabaya: FEBI UIN Sunan Ampel. 